Article

\title{
Anti-Muslim Sentiments and Violence: A Major Threat to Ethnic Reconciliation and Ethnic Harmony in Post-War Sri Lanka
}

\author{
Athambawa Sarjoon ${ }^{1,2, *}$, Mohammad Agus Yusoff ${ }^{1}$ and Nordin Hussin ${ }^{1}$ \\ 1 School of History, Politics and Strategic Studies, Faculty of Social Sciences \& Humanities, \\ Universiti Kebangsaan Malaysia, 43600 UKM Bangi, Selangor, Malaysia; agus@ukm.edu.my (M.A.Y.); \\ nordin@ukm.edu.my (N.H.) \\ 2 Department of Political Science, University of Peradeniya, Peradeniya 20400, Sri Lanka \\ * Correspondance: sarjoona@pdn.ac.lk; Tel.: +60-011-3539-0685
}

Academic Editor: Moojan Momen

Received: 7 June 2016; Accepted: 11 October 2016; Published: 17 October 2016

\begin{abstract}
Following the military defeat of LTTE terrorism in May 2009, the relationship between ethnic and religious groups in Sri Lanka became seriously fragmented as a result of intensified anti-minority sentiments and violence. Consequently, the ethnic Muslims (Moors) became the major target in this conflict. The major objective of this study is to critically evaluate the nature and the impact of the anti-Muslim sentiments expressed and violence committed by the extreme nationalist forces during the process of ethnic reconciliation in post-war Sri Lanka. The findings of the study reveal that, with the end of civil war, Muslims have become "another other" and also the target of ethno-religious hatred and violence from the vigilante right-wing ethno-nationalist forces that claim to be protecting the Sinhala-Buddhist nation, race, and culture in Sri Lanka. These acts are perpetrated as part of their tactics aimed to consolidate a strong Sinhala-Buddhist nation-and motivated by the state. Furthermore, the recourse deficit and lack of autonomy within the organizational hierarchy of the Buddhist clergy have motivated the nationalist monks to engage in politics and promote a radical anti-minority rhetoric. This study recommends institutional and procedural reforms to guide and monitor the activities of religious organizations, parties, and movements, together with the teaching of religious tolerance, as the preconditions for ethnic reconciliation and ethnic harmony in post-war Sri Lanka. This study has used only secondary data, which are analyzed in a descriptive and interpretive manner.
\end{abstract}

Keywords: ethnic minority; Muslims; violence; ethnic reconciliation; post-war Sri Lanka

\section{Introduction}

Sri Lanka, once known for its ethnic diversity and harmonious relationships, which are part of its societal setup, has become notorious for ethnic politics, ethnic conflict, and civil war in the post-independence era. The ethnic conflict, centered on political power-sharing between the majority Sinhalese and the minority Tamils, led to a 30-year civil war that caused further fragmentation of the society and its communities from ethnic, religious, and cultural aspects in an effort to build a united nation as well as a strong state. Since the end of civil war in 2009, Sri Lanka has become the focus of the international community not only for its post-civil war development and transition process but also for the reemergence of ethno-nationalism and intensified anti-minority sentiments and violence, which are now major factors hindering the nation's ability to strengthen the majority-minority ethnic relationship, reconcile grievances of ethno-religious minorities, and strengthen ethnic harmony in the country. These issues have also attracted the attention of international human rights activists and organizations. 
The Muslims (Moors), who form the second ethnic minority in Sri Lanka, have been targeted by extreme nationalist forces that advocate for the preservation of national interests and the majority Sinhalese. In the post-war era in many parts of the country, there have been continuous anti-Muslim sentiments and violence in different forms, targeting ethnic and religious aspects of Muslims and their livelihoods. The major anti-Muslim sentiments that have been expressed by the Sinhala-Buddhist nationalist forces include hate speeches questioning the history and ethnic origin of Muslims, destruction of their places of worship and religious teaching centers, opposition to Islamic fundamentals such as Halal food and Islamic law (Sharia), opposition to animal slaughtering, and criticizing of cultural aspects such as clothing.

Though many argue that the Sri Lankan case is a continued series of anti-Muslim sentiments like those that have posed a number of challenges to Muslims around the world in recent years-of course it may be the case-Sri Lanka's ethnicized Sinhala-Buddhist anti-Muslim sentiments and violence, however, differ significantly from the more "secularist" anxieties innate to particular western contexts such as in France, Switzerland, and Canada ([1], p. 2). Therefore, this study of Sri Lanka will shed a different light on this subject, which will benefit researchers and policy-makers. The study examines how the majoritarian ethno-nationalist groups developed anti-Muslim sentiments and in what way they developed moral oppositions and instigated violent acts targeting the ethno-religious features of Muslims in post-war Sri Lanka. The major objectives of this study are to identify the nature and trends of these anti-Muslim sentiments and the violence instigated by the extreme nationalist forces in post-war Sri Lanka, and to examine the motivating factors and rationales of these sentiments and their impact on the process of building ethnic and religious harmony in post-war Sri Lanka. As many have observed, post-war Sri Lanka has been widely popularized with intensified anti-minority Buddhist sentiments and violence-or, in other words, anti-minority nationalism, particularly against the Muslim community.

\section{Materials and Methods}

This study is descriptive and interpretive in nature and mainly uses secondary data collected from sources such as academic journals, newspapers, reports from research centers, and the internet. These sources have recorded the discourses and number of incidents staged by the Sinhala-Buddhist nationalist forces in opposing the ethno-religious features of Muslims. In addition, they have also analyzed the different motives of the anti-Muslim sentiments and violence developed and intensified in the post-war era. The anti-Muslim violence and motivating factors are critically examined and reported in this paper in the form of direct quotations, quotations of others, summaries, and the authors' interpretation, all of which support the arguments developed in this study. Interpretive research helps to achieve understanding of actions of people in social circumstances and situations. Thus, interpretive studies require the researchers to go beyond providing simple descriptive or explanatory accounts of the phenomenon. They require researchers to "interpret" the phenomenon for the reader. This entails providing an interpretation of what it means, as well as what it is. In this way, the researcher arrives at an interpretation of a phenomenon by developing (subjective) meanings of social events or actions. In religious studies, the interpretive approach aims to provide methods for developing understanding of different religious traditions that can be used by students of different schools to increase knowledge and understanding. It sets out neither to promote nor to undermine religious beliefs.

The rest of this article is divided into three major parts, with concluding remarks at the end. The first part provides a brief history of Sri Lankan Muslims and the nature of their relationship with the Sinhalese, the majority ethnic group in Sri Lanka. By briefly summarizing the historical origin and drawing on the specific nature of the Sri Lankan Muslims, this section further outlines the Muslims' contributions to the social, economic, and political sectors, and the development of the country while maintaining cordial relationships and mutual trust with the Sinhalese and exercising their ethno-religious rights and freedom. The next part provides an extensive examination of the emergence of anti-Muslim sentiments and the nature of violent acts that targeted the ethnic and religious features 
of Muslims-particularly in the post-war context-under six thematic areas: attacks on places of religious worship and religious teaching; the anti-Halal movement and opposition; opposition to animal slaughtering for human consumption and religious rituals; opposition to the practice of Islamic law (Sharia) and the financial system; the formative war on Islamic clothing; and hate speeches against Muslims and Islam. In the discussion part, we critically examine the motivating factors and rationales of these anti-Muslim sentiments and the violence committed by the extreme Buddhist nationalist forces. This study identifies some major factors, and the ways in which they are related, that have motivated these racist sentiments and violence among the Sinhalese-Buddhist nationalists. In conclusion, while positioning the Muslims' ethnic concerns within the emergence of ethno-nationalist and anti-minority sentiments, this study provides some thoughts on ethnic reconciliation and religious tolerance, which are necessary for the empowerment of the ethnic reconciliation process in post-war and post-conflict societies, and particularly in Sri Lanka.

\section{A Brief History of Muslims and Their Relationship with the Sinhalese in Sri Lanka}

The Sri Lankan ethnic Muslims (officially labeled "Moors") form 9.3\% of the national population [2]. Out of the 1.95 million Muslims, two-thirds live outside the north-eastern region and coexist with the Sinhalese, who form about $74.5 \%$ of the country's population. The rest of the Muslims live in the north-eastern region where Tamils predominantly reside. While the origin and history of the ethnic Muslims (Moors) are debatable, it is accepted that Muslims have been living in Sri Lanka since the 8th century [3-8]. Being mostly the descendants of Arab traders, the Muslims in Sri Lanka initially settled in identified port cities around the country and coexisted with the local communities, the Sinhalese and the Tamils, while maintaining socio-economic, cultural, and political ties with them $[7,9,10]$.

History reveals that Muslims in Sri Lanka have for centuries had a peaceful history of co-existence with other ethnic groups and have always been trustworthy and supportive of the rulers $[6,10,11]$. However, when ethno-religious nationalism emerged among the major ethnic groups, the Sinhalese and the Tamil, the Muslims were faced with challenges in terms of fostering their ethnic identity and religious-cultural practices. Particularly, as Jones [12] rightly states, during the post-civil war period, the Muslim minority became the target of ethno-religious hatred and violence from vigilante groups of right-wing Buddhist monks and laypersons who claimed to be protecting the Sinhala-Buddhist nation, race, and culture from the perceived incursions of Islamic extremism, although this started as early as the colonial period, where both the Sinhalese and Tamil leaders attempted to undermine the history and the distinctive ethnic features of Muslims [7,13]. However, Muslim intellectuals and leaders counter-argued and cemented their ethnicity and ethnic identity. Even so, extreme nationalist forces have continuously targeted the Muslims using different means.

Until the end of the civil war, the relationship between the Sinhalese-Buddhists and the Muslims in Sri Lanka had historically been amicable compared to the relationship between the Tamil-Hindus and the Muslims. Muslims had been trustworthy neighbors, traders and trading partners, soldiers, medical practitioners, messengers, and ambassadors to the Sinhalese rulers and the public (See: $[7,8,11])$. Except for the 1915 anti-Muslim riots, no other notable conflict or violence has been recorded in the history of the relationship between the Muslims and Sinhalese. Even though the official history taught in Sinhalese schools suffers from the tales of "Sinhala-Tamil conflict" and the "evil Tamil kings," there are no comparable stories about Sinhala-Muslim conflicts or Muslim conspiracies. Therefore, there are no anti-Muslim "historical memories" recorded in the collective Sinhala psyche that can be tapped into and exploited. The goodwill developed toward Muslims among the Sinhalese leaders and the community has helped the Muslim community to live safely in the Sinhalese-majority areas and uphold their due rights and a number of privileges in practicing their ethnic, religious, and cultural norms and duties without encountering challenges. Additionally, Muslims have continued to safeguard the sovereignty and territorial integrity of the nation even though their ethnicity, ethnic identity, and very existence has been questioned and threatened. 
In the post-independence era, even though politics has become highly ethnicized, Muslims have continued to be on the middle path politically, allying with major political parties representing both ethnic groups. Even during the 30-year-long civil war, the Muslim community and its leaders were not supportive of terrorism and separatist claims and supported government authorities, continually preserving the national integrity and ethnic harmony in the country-even though they faced a number of challenges, such as killing and abductions, forceful displacement, impacts on their livelihood, and negligence of their interests at the negotiation tables-without being a conflicting party. However, in the post-war context, though their grievances were not well recognized, they have become the target of extreme Sinhala-Buddhist nationalist forces in different ways. The increased anti-Muslim sentiments and violence created suspicion among the Muslim community as to whether there would be a century anniversary of the 1915 anti-Muslim violence in the country.

\section{Anti-Muslim Sentiments and Violence in the Post-War Context}

Although the end of the civil war in 2009 put a stop to terrorist violence in Sri Lanka, ethnic violence intensified in different manifestations. This led to the reemergence of ethno-nationalist forces among the Sinhala-Buddhists and they used religious violence against ethno-religious minorities as a means to dominate the social and political spheres in the country. This created a tense situation in which religious minorities have been subjected to continuous, low-intensity attacks ranging from hate campaigns and propaganda to threats, intimidation, minor destruction of property, and occasional physical violence. One minority that has suffered and been marginalized by justice, rule of law, and good governance is the Muslims of Sri Lanka, the second largest minority in the country.

\subsection{The Nature and Manifestation of Post-War Anti-Muslim Sentiments and Violence}

The post-war period in Sri Lanka has seen a wave of incidents such as threats, intimidation, and violence targeting religious symbols, places of worship, and clergy, especially against Muslims. All this indicates that Sri Lanka might be moving toward another conflict between religions [14]. There has been serious sectarian and religious antipathy activities and violence against Muslims in many parts of the country. As part of their anti-Muslim sentiments, the extreme nationalist forces have repeatedly voiced and acted against the ethno-religious and cultural features of Muslims and their practices. Their anti-Muslim sentiments have been expressed in different ways: questioning the practice of Islamic law (Sharia) and its recognition within Sri Lanka's legal system, requesting government authorities to ban Halal certificates, opposition to the consumption of Halal foods, opposition to animal slaughtering for human consumption, opposition to Islamic clothing, and opposition to the practice of Islamic religious norms and duties. In addition to attacks on places of religious worship, there have also been calls to boycott Muslim shops and establishments, all of which have increased tensions, particularly in areas where Muslims and Sinhalese live close to each other. These matters, in the post-war era, have caused concern among democracy and human rights activists locally and internationally. The Sinhala-Buddhist popular extremist group, which is partly a political party, the Bodu Bala Sena (BBS), has rigorously developed and fostered these anti-Muslim sentiments and violence in the post-war era. They have also established an organized forum to destroy Muslim livelihood [15]. Other extreme forces-which are functioning under the major umbrella of the BBS - such as the Sinhala Ravaya (Sinhala Echo) and Ravana Balakaya (Ravana Force), are also spreading anti-Muslim sentiments and violence in the post-war era. Political forces such as Jathika Hela Urumaya (National Heritage Party-JHU), Jathika Nidahas Peramuna (National Freedom Front), and Pivithuru Hela Urumaya are also morally supporting the BBS activities. Their anti-Muslim sentiments have been reflected in different ways, as examined in the major forms outlined below.

\subsection{Attacks on Religious Places of Worship and Teaching Centers}

There have been a series of attacks on the places of worship and religious teachings of Muslims around the country in recent years. The attack in September 2011 on a 400-year-old Muslim shrine in 
Anuradhapura, a town the Sinhala-Buddhist consider historically significant, was the starting point of this issue. This attack was accompanied by a mob of more than 100 people reportedly led by Buddhist monks, spearheaded by Ven. Amatha Dhamma Thero, who said the shrine was destroyed because local Muslims were trying to turn it into a mosque. A noteworthy fact is that this destruction happened in the presence of police officers who did nothing to intervene or stop the attack [16]. Following the Anuradhapura attack, the Sinhala-Buddhist nationalist forces staged a number of direct violent attacks on mosques and other places of worship belonging to Muslims in predominantly Sinhalese areas. This started in April 2012 with the shameful attack on a mosque in Dambulla, a predominately Sinhalese town in the north-central province. A chief Buddhist priest led the attack. A group of about 2000 people forcefully entered the Dambulla Kairiya Jummah mosque and destroyed everything inside. Though there were no casualties, the mosque had also come under a petrol bomb attack in the early hours of the morning preceding the mob violence [16,17]. Two days later, the Prime Minister, D.M.Jeyarathne, also Minister of Religious Affairs, ordered the removal of the mosque from an area deemed sacred to Buddhists and its relocation to another part of the town [18]. This was the first time in Sri Lanka's history where mobs had vandalized a mosque and prevented Muslims' Friday prayers. According to reports, those who attacked the Dambulla mosque were not people from that area but were brought in from outside. The major justification given by the demonstrators was that the Dambulla is a sacred Buddhist area in which no religious practice could be allowed for those other than Buddhists. However, according to the Muslim Council, the main umbrella group of Sri Lankan Muslims, the mosque building was lawfully registered and 60 years old, and it had been there long before the area was declared a sacred zone 20 years ago [18,19].

Following the Dambulla mosque attack, there were attacks and demonstrations against the establishment of mosques and religious teaching institutions in many parts of the country. Some of the worst incidents include the attack and demonstration against Madrasa Darul Quran Baranil Imam at Dehiwala in May 2012, the burning of the Mohideen Jummah mosque in Unnichai village in the Batticaloa district in August 2012, attacks that caused damage to the loudspeaker and sound system of the Mohideen Jumma mosque of Kohilawatte, Wellampitiya, in Colombo in August 2012, and the burning of the inside of the Thakka Mosque at Malwathu Lane of Malwathu Oya, Sinha Kanuwa, Anuradhpura, in October 2012 (on the day of the Hajj festival), which was followed by a protest demanding the removal of the above-mentioned mosque in January 2013. Among the incidents reported in 2013, the worst included the defacing of a wall of the Meera Makkam mosque in Kandy in the early hours of the morning, an apparent threat against Muslims in January 2013, the forced closing of a mosque (Masjithul Araba) in Mahiyangana after raw pork and stones were thrown into the building during Friday prayers on 18 July 2013 (during the holy month of Ramadan), and calculated attacks on the Grandpass mosque in August 2013 (See: [16,19]). Religious tensions and violence instigated by the BBS in Aluthgama in June 2014 are now seen as the crowning event that not only challenged the practice of Islamic religious principles but also the existence of Muslims in the country. Following these incidents, the anti-Muslim sentiments and violence gained international attention, including from the United Nations, which intensified international oppositions to Sri Lanka regarding the violation of minority rights. These international forces also urged the Sri Lankan government authorities to take necessary measures to prevent any further attacks against minority Muslims in the country. Even though anti-Muslim violence became the major topic of discussion and political discourse in the following months, Muslim religious places still continued to be targeted. The stoning attack on the Meera Makkam mosque in Kandy on 11 July 2015, and the throwing of stones on a mosque close to Keththaarama, Colombo, after a quarrel that developed between two groups at a cricket match on 19 July 2015, were some of the more recent incidents (See: [15]). Hundreds of similar incidents of violence have taken place in the last few years, which include the killing of four Muslims, the injuring of many, the destruction of their places of worship, and challenges to their faith practices and duties. All these incidents have taken place under the mask of a disgraceful "Buddhist-cleansing of Sri Lanka" - propagated by the BBS and other extreme nationalist forces. However, the actions of 
the BBS and other nationalist forces are clearly against the teachings of Lord Buddha and everything Buddhism stands for and even border on acts of terrorism. Buddhism emphasizes tolerance and non-violence in its original pre-Sinhala form, but, in the name of Buddhism, the extreme nationalist forces and associated organizations break the law at will and sow the seeds of new ethno-religious conflict in post-war Sri Lanka.

\subsection{Anti-Halal Movements and Oppositions}

The oppositions against consuming Halal foods and the labeling of the Halal certificate on food items are a serious threat to the religious practice of Muslims in post-war Sri Lanka. One of the major fundamentals of Islam is its teaching that its followers must consume only Halal foods. Accordingly, Halal is lawful and permissible, and Haram is prohibited and should be avoided. The All Ceylon Jamiatul Ulama (ACJU), the main decision-making theological body for Sri Lankan Muslims, was given the responsibility of monitoring and issuing Halal certificates, the act of which was not seen as a serious problem until the BBS started its hate campaign in 2012. Since then, the Halal issue has become the centerpiece of the BBS campaign, which has led to post-war Muslim concerns and received international attention [20]. As Hussain [20] rightly pointed out, Muslims have traditionally had no problem identifying Halal food items, but with the wide spread of packaged synthetic foods, identification suddenly became a real problem because these foods could contain forbidden ingredients that have not been listed on the packages. Therefore, there was a need for Halal certification, and the ACJU met this need. It was further found that exporters would be badly handicapped in certain markets without Halal certification, and the ACJU obliged by meeting this need as well. There was nothing secret, nothing criminal, and nothing deleterious to the national interest in regard to the actions of the ACJU in issuing Halal certification. However, the BBS and other nationalist groups have openly called for boycotting Halal consumer products that are associated with Muslims. According to them, ACJU makes money from Halal certification and uses it for nefarious purposes such as to propagate Islam, to expand Islamic communities, and to build mosques ([12], p. 126). These forces, in fact, mobilized the network of Buddhist organizations and groups to boycott Halal-labeled foods through electronic media [21]. All these agitations ultimately led the government authorities to stop the Halal certificate issued by the ACJU and to transfer that certification function to Halal Accreditation Council (HAC), a limited guarantee company, from 1 January 2014 [22]. In fact, government authorities failed to take any action to stop or to control these anti-Halal campaigns until they had done too much to wreck the Sinhalese-Muslim relations.

\subsection{Oppositions to Animal Slaughtering}

Islamic principles guide its followers on how to slaughter animals for food and other ritualistic purposes. The tendency of Islamic law (Sharia) is to make the process of slaughter more humane by reducing the suffering of the animal in the best possible manner. The idea in Sharia is to stop cruelty to animals; so, in a sense, this is a common ground for decent people, both believers and non-believers of Islam [23]. However, in the post-civil war era, it has not only been this Quranic process of slaughtering but also the slaughtering of cattle for meals and other purposes that has been questioned and opposed by the Buddhist nationalist forces, with the reasoning that it is inhumane and an affront to Buddhist values and the majority's sensibilities.

The opposition to animal slaughtering has caused a number of difficulties for the Muslim community when it comes to performing their religious rituals. This is especially true during Hajj, where Muslims perform udhuiya or Qurbani by slaughtering cattle. This is not only a religious duty for Muslims but also strengthens social solidarity by distributing meat to relatives, friends, and the poor. The festival becomes an occasion for affirming social solidarity and compassion for the poor. There is nothing in these practices that warrants the Buddhists' moral objection against cattle slaughtering to perform udhuiya [20]. However, due to the anti-animal slaughtering campaigns of these nationalist forces, during the Hajj festival of 2012 some local government offices reportedly refused to issue 
permits for animal slaughter. In September 2012, the Kandy Municipal Council also passed a resolution banning animal slaughter within the municipal council limits [24]. This anti-animal slaughtering issue has continued in many parts of the country, mainly to oppose the Muslims' religious practices. At an extreme level of opposition, on 24 May 2013, a Buddhist monk succumbed to his injuries and died after setting himself on fire in front of the Kandy Dalada Maligawa (Temple of the Tooth) to protest cattle slaughtering by Muslims [25]. This incident intensified the anti-animal slaughter protests of the BBS and the other extreme nationalist forces, causing a tense situation in the following months in many parts of the country. With the continued pressures from the BBS and other Buddhist nationalist forces, in January 2016 the country's President ordered the relevant government authorities to find possible ways to import meat to cater to the local requirement from foreign countries and ban the slaughtering of cattle for meat [26]. This has created suspicions among Muslims, especially since it is seen as a strategic step to sabotage their economic activities as well as their religious practices. Animal slaughtering, especially slaughtering cows, remains a very sensitive issue among certain sects of the Sinhalese-Buddhist community, which they use to sow hatred and exacerbate division among the communities.

\subsection{Opposition to the Practice of Islamic Law (Sharia) and Financial System}

The practice of Islamic law (Sharia) and its recognition within the legal system of Sri Lanka and Sharia-related activities have also been highly targeted by the extreme nationalist forces in the post-war era in Sri Lanka. Islam guides its followers based on the Al-Quran and the teachings of Prophet Mohamed (Sunnah) in every aspect of human life. It also outlines how to resolve issues based on Islamic principles and guidelines (i.e., Sharia law and court system), and also how to conduct financial activities (i.e., Islamic Finance).

The BBS has continued to oppose the practice of Islamic law and the Islamic banking system in Sri Lanka, urging the government authorities to ban this system, calling it illegal and saying it contradicts the interest of the common law. Addressing a media briefing on 9 June 2015, the chief executive officer of the BBS, Dilanthe Withanage, said that "Islamic (Sharia) finance is a threat to Sri Lankan Buddhist values, human rights, and national security" ([19], p. 8). He further claimed that Islamic banking is a mechanism for funding terror, fundamentalism, and extremism. He also asserted that these are a kind of financial Jihad through funds and charities [19]. Furthermore, Withanage demanded that the Criminal Investigation Department and relevant authorities take the necessary steps to regulate the Islamic financial system and not promote it. Ultimately, on 23 June 2015, the BBS leaders, including Ven. Gnanasara Thero, visited the Central Bank to examine the existing Sharia-compliant banking system in Sri Lanka. They even handed over a letter to the Central Bank governor emphasizing the banning of the Sharia banking system in Sri Lanka [19]. In August 2015, the chairman of Sinhala Rawaya, the Venerable Akmeemana Dayarathana Thero, stated that "Muslims are moving for separate laws for themselves when there is a common law for the country. It is very funny when Muslims talk about Islamic law while they lead the way in drug transactions and the like" ([19], p. 12). Similarly, in a number of occasions, the BBS leaders have continued to criticize and oppose the Islamic law and financial system in practice, and urged the government authorities to ban them.

\subsection{Formative War on Islamic Clothing}

Apart from the attacks on Muslim religious places of worship and Islamic law, the religious-cultural practices of Muslims, such as polygamy, inter-marriage, and Islamic clothing such as the abaya, head scarf (hijab), and face covering (niqab), have also come under fire from the Buddhist nationalist forces, creating serious concerns among Muslims and non-Muslims in the country as well as in the Islamic world. In particular, the popularization of Islamic clothing such as the abaya and variants of the hijab are often used as a discursive battlefield against Muslims in Sri Lanka. Due to these anti-abaya and anti-hijab sentiments, Muslim women are compelled to restrict their movements while wearing their religious-traditional clothing in Sinhalese-predominated areas. Besides that, these 
Sinhala-Buddhist nationalist forces have also urged the government authorities to impose restrictions on Islamic identity-based clothing being worn in public places. In many schools of prominent towns, Muslim girls are advised, and sometimes compelled, to remove their hijabs and long Panjabi trousers and hide them in their school bags. Meanwhile, there were a few events of imposing violence on Muslim women for wearing Islamic clothes in many predominantly Sinhalese towns (See: [21,27]). This indicates that the Muslim ethnic and cultural identity has become a liability in post-war Sri Lanka. However, as far back as 1980, the Ministry of Education, by a circular issued to all Zonal Directors of Education, instructed that Muslim girls must be permitted to attend schools in their traditional Punjabi attire, which includes a white frock, a trouser, and a shawl [27].

There are some influencing factors that have induced the nationalist forces to oppose and target Islamic clothing in the recent past. It is true that until the mid-1980s, most of the Sri Lankan Muslims-especially women-were commonly seen wearing the sari/saree and the shalwar kameez. The majority of Muslim women in the north-eastern region were seen loosely covering their hair with their sarees in what is locally referred to as the mukkadu-style [21,28]. However, with the increase of reformist movements, which focus on practicing the pure form of Islamic tradition, the clothing of Muslim women has also changed. These reformists strongly encourage the wearing of clothing similar to that of Arab women, especially when they go out. This clothing culture has become the fashion of Muslim women and, as a result, the abaya and hijab are the predominate clothing of choice. There is no reason to oppose this clothing except that it symbolizes the Muslim religion.

\subsection{Hate Speech against Muslims and Islam}

One of the strategies that the Sinhalese-Buddhist nationalists developed through their anti-Muslim sentiments is the hate speeches against the ethnic origin and cultural and religious practices and activities of Muslims. Well-organized and well-financed anti-Muslim campaigns have burst onto the scene, infringing upon the life of Muslims over the last few years. These hate speeches attempted to portray the Muslim communities in Sri Lanka as communities of Islamic terrorists who are attempting to turn Sri Lanka into a "Muslim country." These nationalists have used both printed and electronic media, including social media such as Facebook and Twitter, to further propagate their anti-Muslim campaigns among the Sinhalese. On many occasions, the leaders of these nationalist forces publicly spread their hate speeches, using coarse, derogatory language to criticize Muslims and their religious leaders and to tell the Sinhalese majority to not rent their property out to Muslims.

The BBS spokesman, Mawathagama Pemananda Thero, in a public meeting held in Kandy on 17 March 2013, stated that "the Quran orders Muslims to spit three times on the meals they offer to non-Muslims" ([29], p. 22). However, as Zuhaira [29] argues, there is no such statement in the Quran. This statement was clearly propaganda designed to pit the Sinhalese against the Muslims. According to Akmeemana Dayarathana, who founded another ultra-nationalist Buddhist group, Sinhala Echo, Muslims are trying to convert people by building too many mosques and even by having too many children [30]. On 12 April 2014, opposite the Slave Island police station in Colombo, the BBS head, Gnanasara Thero, alleged that "the Quran allows Muslims to acquire the wealth of non-Muslims through fraudulent means" ([29], p. 22).

The most derogatory speech of Gnanasara Thero was the one he delivered in Aluthgama on 15 June 2014, the day riots erupted in Aluthgama in Beruwala. He incited the Sinhalese to finish off the Muslims, using the derogatory term "Marakkalayas." In the presence of a rousing crowd, he said that "if one "Marakkalaya' lays a hand on a Sinhalese, that will be the end of all of them" [31]. In his speech, he threatened to destroy Muslim businesses in Aluthgama, Beruwala, and other places. He also instructed his listeners to grab any bags with a Halal sign and throw them on the ground. Additionally, he asked his audience to fight against the minorities [31]. His speech is strongly believed to have contributed to the anti-Muslim violence that erupted that evening in many Muslim villages in Aluthgama where four people were killed and more than 100 Muslim-owned businesses were destroyed in the violence [31]. The United Nations High Commissioner for Human Rights described 
the incident as one of the worst incidents of sectarian violence in Sri Lanka's recent history (See: [32]). It is worth noting that although the government had arrested many politicians, journalists, religious leaders, and human rights activists under the Prevention of Terrorism Act (PTA) that deal with incitements of communal tensions, government authorities, police, and armed forces have not yet pointed to any of the speeches by Gnanasara Thero or other leaders of the Sinhala-Buddhist nationalist forces as the instigators that caused the communal tensions and breakup of communal relations in and around the Aluthgama area on 15 June 2014.

As a new strategy, the nationalist forces used the "Sinha Le" campaign to attack Muslims. The "Sinha Le" campaign first rose to prominence on social media platforms toward the latter part of 2015. It originally began as a poster campaign, which carried an image of a lion taken from the national flag along with the words "Sinha" (lion) in yellow and "Le" (blood) in red. Within a short period of time, a large number of "Sinha Le" posters appeared in public spaces, as well as private vehicles, most notably on three-wheelers, buses, and vans. On the night of 2 January 2016, the words "Sinha Le" were sprayed across several gates and walls of Muslim-owned houses in Nugegoda, a suburb of Colombo. This was widely seen as an act designed to provoke ethnic tensions; it carried the message that Muslims were the campaign's main target. A group calling itself the Sinhale Jathika Balamuluwa endorsed the "Sinha Le" campaign, thereby giving it a public face by distributing "Sinha Le" stickers in many towns in the following months. This sudden display of "Sinha Le" posters and stickers in public places and on social media gave the appearance that they were part of an organized political campaign seeking to further expand Sinhala nationalism and anti-minority sentiments among the majority Sinhalese in Sri Lanka (See: $[29,33])$.

\section{Discussion}

Historically, the ethnic identity of Sri Lankan Muslims was formed and developed through their religious-cultural attachment and practice. However, the extreme Buddhist nationalist forces in the post-war era have targeted the ethnic and religious identity of Muslims and their religious practices in public life. Respecting the religious-cultural distinctiveness of all groups and freely allowing them to practice their religion are the pre-conditions to establishing ethnic cohesion and religious harmony in any ethnically plural society. In fact, all religions teach the importance of respecting the faith and principles of other religious groups, including minorities. Muslims in Sri Lanka have also been practicing their religious and cultural beliefs and norms without harming others. Until the emergence of the extreme nationalist forces, no serious opposition has emerged among the Sinhala-Buddhists regarding the practice of Islamic fundamentals, Halal foods, animal slaughtering, and other Muslim religious affairs.

In particular, the anti-Muslim sentiments, agitations, and violent oppositions took a turn for the worse following the release of the 2012 census reports that indicated a higher population growth among Muslims than Sinhalese-Buddhists, who account for about 70\% of Sri Lanka's population. (However, ethnic Sinhalese form about 74.5\% of the country's population) [2]. Muslims, who formed only $7.5 \%$ of the country's population in 1981, had increased in number to make up 9.3\% in 2012, which caused the Sinhalese-Buddhists to predict and propagate that Sri Lanka would become a predominantly Muslim country by 2060. Based on this reason, Sinhala-Buddhist nationalist forces have been targeting Muslims in different ways. However, there are a number of factors that also influenced the population change in Sri Lanka. For instance, the Tamil population growth rate dropped during that 30-year period because of the huge number of Tamil deaths during the civil war and especially because of mass migration. Also, due to a number of reasons, the birthrate in the Sinhalese community decreased during this period. All these factors have affected the calculation of the ethnic composition of the national population. As Hussain [20] rightly pointed out, the Muslims' 2\% leap forward from 1981 to 2012 is something thoroughly abnormal. Between 1881 and 1981, the Muslim population was virtually static: $7.17 \%$ in 1881 and $7.56 \%$ in 1981 [34]. On the other hand, the Sinhalese population increased 
from $61.53 \%$ in 1881 to $69.30 \%$ in 1981 , and $74.90 \%$ in 2012 [2]. Over 100 years the Muslim population had increased only marginally, by $0.39 \%$.

It is worth noting that the post-civil war anti-Muslim sentiments and violence were not a sudden occurrence among the Sinhala-Buddhist nationalists. The root of these sentiments emerged during British rule. The Muslims' dominance in trade and business and their economic prosperity in the country caused the Sinhalese-Buddhist nationalists to question the origin and modes of the livelihoods of Muslims. There were a number of writers, dramatists, journalists, and monks who wrote extensively, glorifying the heroic deeds of the Sri Lankan kings, recalling the victories against foreign invasions and also denouncing foreign traders, as well as urging Sinhala people to boycott the shops of Muslim traders. It is worth noting that the writings of Anagarika Dharmapala during this period were mainly targeting the Muslim traders. To quote an example, in 1915, he wrote:

“...The Muhamadans, an alien people...by shylockian methods became prosperous like the Jews. The Sinhalese son of the soil, whose ancestors for 2358 years has shed rivers of blood to keep the country from alien invaders....are in the eyes of the British only vagabonds...The alien South Indian Muhamadan come to Ceylon, see the neglected villagers without any experience in trade. The result is that Muhamadan thrives and the son of the soil goes to the wall..." (Quoted by Jayawardena, [13], pp. 24-25).

Darmapala's writings created a feeling of anti-Muslim sentiment among Sinhala-Buddhists the following year. This ended with the historic anti-Muslim violence in 1915 that ended with destroying millions worth of trade and business properties of Muslims in Sri Lanka (See: [13,35,36]).

The vulnerable position of Muslims in post-civil war Sri Lanka is also partly attributed to the newly emerged political scenario in the post-war context. The war itself was actually conducted to defeat the minorities' challenges to the united and unitary form of Sri Lanka. The defeat of the LTTE formed a competing power vacuum at the societal level, which not only caused the revival of ethno-nationalist forces but also an ethnic consciousness among Sinhalese toward conceptualizing "Sri Lanka" as a "Sinhala-Buddhist nation" and "a strong unitary state" in which there is no place for the advancement of other ethno-religious groups and regional autonomy for them. One can find that anti-Muslim sentiments and violence intensified by these nationalist forces was also a reaction to the increased claims of Muslims for territorial or regional autonomy in recent years, which was seen by the Sinhala-Buddhist nationalists as another threat by minorities to their vision of consolidating a strong unitary state of Sri Lanka. With the intense ethnic conflict and civil war, Muslims in the north-east became politically mobilized and demanded a unit of territorial autonomy in the negotiated settlement. Unfortunately, their interests and claims for autonomy have continued to be marginalized in the peace process. Since successive governments were attempting to defeat the Tamils' autonomy and separatist claims through military means, it was not feasible for Muslims to intensify their autonomy demand. However, when the United National Front (UNF) government attempted to find a negotiated settlement through a power-sharing mechanism in 2002, the Muslim community in the east mobilized and collectively remembered their demand for autonomy. The Olvuil revivalist conference held on 29 January 2003, released the Oluvil Declaration, which was viewed by the Sinhala-Buddhist nationalist forces as a milestone in the development of Muslim ethno-nationalism and their demand for autonomy (See: [37-39]). Also, these forces found the predominately Muslim South-Eastern University located in Oluvil in the heartland of the proposed Muslim-majority province as a center of Islamic revivalism and nationalism in Sri Lanka. From this point, nationalist forces such as JHU became critical of the Muslim demand for autonomy. The Sri Lanka Muslim Congress (SLMC) also officially put forward the Muslim autonomy demand for the first time in 2006, and this may have motivated the Sinhalese-Buddhist nationalists to demand demerger of the north-eastern provinces in order to sabotage the Muslims' autonomous claim. This is because the Muslim autonomy demand emerged in the context of the merging of the east with the north through the Indo-Lanka accord as a mechanism to accommodate the Tamils' autonomy interest (See: $[37,40])$. During the 2008 election for Eastern provincial council, Muslim leaders intensified their thirst for autonomy. When all the attempts by 
the Muslim leaders to control the Eastern provincial council failed, they intensified their Kalmunai administrative district demand. With the defeat of the separatist claims of the LTTE, Muslims became the target of Sinhala-Buddhist nationalism.

Therefore, it can be argued that the anti-Muslim sentiments expressed and the violence committed by the Sinhalese-Buddhist nationalist forces were highly motivated by the intensified claims of Muslims for decentralized power and greater political autonomy, and further motivated by the Norway-facilitated peace process which attempted to accommodate the minorities' autonomy demands through the power-sharing mechanism. The issues of constitutional devolution and foreign-mediated negotiation from 2000 through 2004 were a source of great anxiety to Sinhala-Buddhist nationalists, who had long opposed devolution, foreign intervention, and any solution to the ethnic conflict. Norway's involvement as facilitator in the Sri Lanka ethnic conflict resolution process created a space for the nationalist forces to mobilize masses and restage their nationalist agenda [41]. With the end of civil war, these nationalist forces were able to build anti-minority and anti-Muslim consensus and sentiments, in particular among the majority Sinhalese masses, which later on strengthened their politics against minorities.

It is noticeable that the anti-minority sentiments developed and imposed on minorities in the post-war context has also been triggered by the sense of powerlessness the Sinhala-Buddhist majority feels in a global context. Although the Sinhalese form a clear majority in Sri Lanka, they are a global minority ethnic group and have long felt surrounded by non-Buddhists in South Asia. Many among them understandably argue that they do not have any allies if their religion becomes a target, while the Tamils and Muslims have global friends who can support them and uphold their cause. The Sinhalese people and Sinhala language have only Sri Lanka to call home. This fear and self-imposed isolation, when coupled with notions of sinhadipa and dhammadipa, contribute to Sinhalese Buddhists viewing pluralism pejoratively and framing majoritarianism as an entitlement [42]. Therefore, historically, religious and political leaders and ethnic entrepreneurs have emphasized the fact that Sri Lanka is a Sinhala-Buddhist country and the importance of opposing any threat to Sinhalese and Buddhism in any form and from any source. As Jones [12] argued, globalization often disrupts local identities, eviscerating traditional, birth-given roles, and produces confusing outcomes. In response to the deterioration of power away from national governments and toward global organizations, right-wing nationalism offers a return to the stable borders of the nation-state. Moreover, nationalist opposition to global flows can be read as a means of maintaining ethnic hegemony. In the discourse of the BBS, Sri Lanka is the only predominantly Sinhalese country in the world where a 2000-year-old Theravada Buddhist civilization has survived challenging the three waves of colonialism. As a result, this marginalized feeling has created fear and insecurity among the Sinhala-Buddhist nationalists and incited opposition to minorities, so as to safeguard the Sinhalese and their religion. Since this ethno-nationalism has received major support from government authorities as a means for them to sustain power, there has been no immediate justice for the minorities.

It is worth noting that during Sri Lanka's long civil war, religion was an important part of the collective identity and social narratives of many ethnic groups. Though the civil war was not strictly based on religious conflict, identity cleavages between the Hindus and Sinhalese were central to understanding the war. Immediately after the independence, the Sinhalese rulers attempted to institutionalize Buddhism and Buddhist-cultural dominance in socio-political domains legally and structurally. The adaptation of Sinhala as the only official language, prioritizing Buddhism as the major religion in the country, changing the name of the country from Ceylon to Sri Lanka (a Sinhalese name), and promoting Sinhalese colonization of predominantly Tamil areas in the north-east were some of those attempts. In fact, the promotion of Sinhalese identity—religion, culture, and language-was a driving force for Tamils' grievances, and the Tamil nationalist groups like LTTE responded to these grievances with terrorism and insurgency [43]. During the 30-year civil war, religious identity and practice were highly targeted by both government forces and the LTTE. For example, the LTTE massacred Buddhists at prayer in Anuradhapura in 1985, bombed the Buddhist Temple of the Tooth 
in 1998, and expelled more than 75,000 northern Muslims from their homes in 1990 mainly for being Muslim and mobilized under a Muslim political party. The targeting of innocent civilians, particularly Sinhala-Buddhist civilians who were claiming Sri Lanka as the holy land for Buddhism, caused the religious and nationalist groups to oppose any peace negotiation with the Tamil rebels and to support war against separatist claims. The LTTE was primarily a secular, nationalist movement that became increasingly brutal over time. Therefore, the government tended to align and define itself solely in terms of Sinhalese nationalism, for which defense of Buddhist heritage and identity are important obligations. Similarly, Sinhala nationalists accused Muslims of seducing "our daughters" and their moneylenders of "making us slaves" ([44], p. 17).

This religious motive of war and opposition to peace caused the state military forces to destroy religious identities and to strengthen the Buddhist symbolic identities in many parts of the north-eastern region in the post-war context. Hundreds of new Buddhist temples were established and the names of many traditional Tamil villages were renamed with Sinhala pronunciation (See: [45]). Some Buddhist monks were among the most vocal opponents of compromise within the majority community. For example, monks took to the streets to protest Norway's mediation of the ethnic conflict resolution process, leading to a 2002 cease-fire agreement between the LTTE and the government. With the breakup of the cease-fire agreement and deadlock in the peace process, these Buddhist monks' organizations and nationalist forces were highly critical of the external influence in Sri Lanka's ethnic conflict resolution process and any kind of resolution package challenging the county's territorial integrity. There were higher motives of ethno-religious revivalism and demands for power-sharing among the Muslim community during this period, as explained earlier in this section. Also, the recent revivalist and political mobilization among the Muslim community became the major internal challenge for the Buddhist nationalist forces to consolidate a strong Sinhala-Buddhist nation-state in the post-war context. Therefore, these forces set their sights on the religiously-inclined ethnic Muslims. In short, the civil war limited the anti-Muslim religious hatred and the violence of ethno-nationalist forces among the Sinhalese. However, the war, which was unsuccessful for many governments-but was strategically succeeded by the Rajapaksa regime with the motives of these ethno-nationalist forces-incited them to plan and execute these anti-Muslim sentiments and violence.

In the post-war context, Buddhism in Sri Lanka is characterized as being violent per se. Although religious phrases may be used in violent rhetoric, it is worth noting that Buddhism itself is not violent. Therefore, as Graves [44] rightly pointed out, we should look at how the religious actors imagine and apply religion to provide legitimacy to specific political acts and violence. In fact, in Sri Lanka, both the rulers and the nationalist forces have used religion as a hegemonic means to extend their dominance in society and hold on to power. The mob violence by these nationalist forces had other purposes apart from religion, and were often politically organized or induced. Although there were pressures and voices that encouraged controlling the anti-minority-particularly anti-Muslim sentiments and violence so as to restore ethnic and religious harmony in the post-civil war context-the rulers and the respective authorities have failed to do so, believing that through this means they can preserve and sustain their power. In fact, in Sri Lanka, the constitution has guaranteed religious rights to all religious groups and freedom to practice them without the interference of others. The constitution has also ensured the role of the state apparatus to protect and promote all religious groups. However, in the ethnic conflict and intensity of civil war, and in the post-war contexts, minorities' opportunities to practice their religious freedom was challenged, partly due to the state's failure to establish a cohesive and conducive socio-political context to protect and promote inter-religious harmony and tolerance.

It is worth noting that the post-war anti-Muslim violence intensified by the Buddhist nationalist forces was also strongly supported by government authorities, which used the violence as a strategic means to sustain power. It was believed that one of the brothers of President Mahinda Rajapaksa, Gotabaya Rajapaksa, morally supported these nationalist forces, particularly the BBS. His official presence in a number of meetings of BBS clearly justified this claim. As Hensman [46] rightly pointed out, the regime's backing for the perpetrators was clear from the behavior of the police, who allowed 
the thugs to wreak violence on helpless Muslims with impunity, but arrested the moderate monk Wataraka Vijitha Thero, who had spoken up for the rights of minorities, after he had been severely assaulted and left tied up on the road by the BBS. However, the government authorities denied their links with these extreme nationalist forces. Instead of restoring democracy and good governance, and accommodating the concerns of the minorities, the government of former President Rajapaksa has steered the country toward authoritarianism and further nurtured a majoritarian mindset. In so doing, support for Sinhala-Buddhist ethno-nationalism was used as a deliberate political strategy to consolidate the majority vote-base [29]. Muslims and Christians then became the major targets of these nationalist forces.

Similarly, as Isaacs [47] argues, in Sri Lanka, the dismantling of the Buddhist hierarchy coupled with a shortage of material resources has also encouraged many monks to embrace radicalism. Variations of this behavior can even be seen at the local level. Monks from historically wealthy temples tend to support a more traditional interpretation of Buddhism, while monks from historically poor temples tend to embrace a more radical message. The effect of this competition in resources has been a general increase in both the radicalism and political activism advocated by monks. Especially since the 1970s, a growing number of monks have endorsed radical ethnic politics as a means of self-promotion [47]. It was during this period that a series of influential monks began to preach against religious minorities. In the post-war context, organizations like the BBS are internally divided and composed of monks seeking individual notoriety by appealing to the ethnic insecurities of their base. These organizations are evidence of the extent to which the Buddhist religious economy has become a free market dominated by entrepreneurs whose fortunes are limited only by their radicalism and rhetorical skills. Faced with a resource deficit and the autonomy to preach as they please, Sri Lanka's Buddhist clergy have both the means and the motive to promote a radical anti-minority rhetoric [47]. Therefore, the Buddhist nationalist forces have intensified political violence against the ethno-religious minorities, even with the prevailing peaceful Theravada Buddhism ideology in post-war Sri Lanka. This shows that the fault is not with the teachings of Buddha but in the manner of the organization of the Buddhist clergy and the political role they are permitted to play. There are worries among the liberal Buddhist-Sinhalese that for many years, instead of practicing what Buddha has preached, such as Ahimsa (non-violence), Karuna (compassion), Metta (affection), and Maithriya (loving-kindness towards fellow humans), the Buddhist clergy in Sri Lanka has instead engaged in un-Buddhist practices, such as racist politics, even promoting Sinhala-Buddhist chauvinism and hatred toward minorities.

It is also worth noting that, although the extreme nationalist forces are spreading anti-Muslim sentiments and committing violence against Muslims, there have been no formal Sinhala-Muslim issues in the country in the post-civil war era. The majority of the ordinary Sinhalese and the Muslims have no problems with each other. Also, the majority of the Sinhalese have not been affected by anti-Muslim sentiments as yet. It is clear, however, that the issues imposed on Muslims are being artificially created by extreme elements, but it is a surprise to see why the majority Sinhalese failed to oppose these anti-Muslim sentiments and the violence encouraged by the extreme elements within Sinhalese society. No strong civil society institutions or forums are available among the Sinhalese to oppose the anti-Muslim sentiments and violence, only a few individuals. It is true that the end of civil war and the unification of the country's territory by defeating the separatist claims have intensified a nation-wide ethnic-consensus among the majority Sinhalese toward conceptualizing and consolidating Sri Lanka as "the one and only state for Sinhala-Buddhists in the world." Actually, the war against the separatists was also highly motivated or supported by the majority Sinhalese on the basis mentioned above. As discussed earlier, Muslims were also challenging the concept of the consolidated Sinhala-Buddhist state of Sri Lanka through their intensified demands for autonomy and decentralization. This Sinhalese consensus may have also influenced the stance of majority Sinhalese toward responding to anti-Muslim sentiments and violence in the post-war era.

There is an argument that the Sri Lankan case of anti-Muslim sentiments and violence is part of the intensified anti-Muslim sentiments developing in many parts of the world in recent years. It is 
true to a certain extent. Muslims around the world, especially those living as minorities, are facing serious challenges in practicing their religious-cultural principles. However, Buddhist-nationalism rarely relates to any of the anti-Muslims violence, except in the case of Rohingya Muslims in Myanmar. Most of the cases in Europe are motivated by opposing Islamic fundamentalism and terrorism. The Indian version of anti-Muslim sentiments and violence is highly motivated by the Hindu-nationalist forces which are aiming to consolidate a strong Hindu raj (state). Even in the Myanmar case, most of the Rohingya Muslims are non-citizens and marginalized, and have been clamoring for recognition and status within the state. Their role in the socio-economic and political sphere in Myanmar is also limited (See: [44,48,49]). However, the case of Sri Lankan Muslims is different, to a certain extent. Muslims have long been living there with equal status to the Sinhalese and Tamils, and they have a good record of relationship with other ethnic groups and the rulers. They are a recognized ethnic group and experience the rights and privileges enjoyed by other ethnic groups. Also, the Muslim community in Sri Lanka has not been strongly supportive of religious fundamentalism, terrorism, and separatism, but has been committed to preserving sovereignty and the territorial integrity of the country. Therefore, the intensified anti-Muslim sentiments expressed by the Sinhala-Buddhist nationalist forces in the post-war era must have different motivations from those examined above.

In spite of all that has happened, Muslims also contributed to the Sinhalese rulers during and after the civil war through a number of means. They never formed any alliance with the separatists, who morally and physically fought against the government forces and government policies. Muslims continued to support governments' initiatives to eradicate terrorism through war and other means, including via international campaigns. During the civil war period, many Muslim leaders were able to amass moral and financial support from the Arab World in order to not only continue the war but also to assist in the improvement of the country's economy and infrastructure. Although Muslims faced severe oppositions and challenges to practicing their ethno-religious and cultural duties and norms, they never resorted to violence to save themselves and did not beg any outside forces to rescue and grant them safety and security. Instead, they used non-violent means such as dialogues and discussions to appeal to the rulers and find solutions based on the teachings of Islam. All these actions justify the commitment of Sri Lankan Muslims and their leaders to promoting ethnic relations, ethnic harmony, and national and territorial integration of the country. Therefore, the anti-Muslim sentiments and violence directed by the extreme nationalist forces in the post-war era are unjustifiable and indicate the nation's inability to accept and tolerate religious diversity in the society. On the other hand, the inability to control the anti-Muslim sentiments and violence that has grown throughout the post-war era has also indicated the inability of the political and security structures of Sri Lanka to accommodate ethnic and religious diversity within the larger political sphere. As Jeyatilleke [50] rightly points out, for pragmatic and strategic reasons, the Sinhalese and the government have to understand that the anti-Muslim surge is profoundly counterproductive and almost suicidal, and that it will only lead to further isolation of the country and the majority Sinhalese. The minorities, who are seen by Sinhala extremists as Trojan horses, are in fact the bridges between the Sinhalese and the outside world, given that there is no other collectivity or concentration of Sinhalese elsewhere. Racism and intolerance based on blood ties are not part of the Buddhist ethos. Therefore, the public and the politicians have to think about the future of the country, so as to build ethnic harmony and religious tolerance, both of which are needed in the post-war ethnic reconciliation process in Sri Lanka.

\section{Concluding Remarks}

In a plural society, protecting the civil rights and ethno-religious and cultural dignity of all ethnic groups, including minorities, is of utmost importance for the reconciliation of ethnic and religious differences. However, post-war Sri Lanka has failed to reconcile ethnic grievances and, to a greater extent, build ethnic cohesion. Although the end of the civil war had instilled hopes among locals and the international community that Sri Lanka would return to a societal peace and rebuild broken ethnic relations, nothing positive has happened. Strictly speaking, reconciliation implies a process 
of restoring the shattered relationship between actors [51]. Post-conflict peace building cannot be achieved unless a more comprehensive, multidimensional, lasting effort to rebuild the emotional and physical aspects of a shattered society is adopted, such as building hospitals and schools and so forth [52]. Ethnic reconciliation, therefore, implies a process of restoring the broken or disturbed relationships among different ethnic groups or communities or even persons that belong to different ethnicities. Also, reconciliation underlines how mutual recognition, acceptance, and tolerance of communities are fundamental. However, Sri Lanka's vision of reconciliation is not constructed on this model. Instead, denying the very existence of an ethnic crisis in the country, Sri Lanka has purported the problem to be and labeled it as "terrorism" and allowed room for the reemergence of extreme forces of ethno-nationalism in the post-civil war era. Contrary to the expectations of all, these extreme nationalist forces have extended anti-minority sentiments and violence in the post-civil war era. As discussed earlier in this paper, the Muslim community has become the major target of these forces, posing serious concerns. The ethnic and religious aspects of Muslims have been seriously targeted through hate speeches, oppositions, agitations, and violent attacks. However, it is worth noting that Muslims have not resorted to violence to restore their rights and save themselves from being targeted, despite the sentiments and violence they have had to face. They have never used violent means to destroy another's religion. However, Muslims have been and still are victims of ethno-religious nationalism and violence in Sri Lanka.

As identified in this paper, Sinhala-Buddhists' fear and sense of being a minority and powerless in the regional and global context motivated them to protect and promote Buddhism and Sinhala-Buddhist ethno-religious aspects and their dominance in the socio-political domains in Sri Lanka. This fear also motivated them to oppose any kind of minority demands for power-sharing, autonomy, and recognition, and these claims were viewed by them as threats to the national and territorial integrity of the country. Additionally, lack of material sources, autonomy, and competition for power has also motivated the radicalism, minority rhetoric, and political activism among monks in recent years. All these factors intensified the anti-Muslim sentiments and violence and increased the challenge of enhancing ethnic and religious cohesion in the post-war era.

Giving more social and political space to the extreme nationalist forces to spread their anti-minority sentiments and campaigns would definitely undermine and challenge the ongoing different religious and inter-religious efforts that are attempting to create and promote the post-war reconciliation process in Sri Lanka. Religious groups, leaders, and institutions could spread the message of peace in effective and sustainable ways. Inter-religious teaching initiatives, which aim to bridge ethno-religious divides and establish a discourse of understanding, provide concrete evidence that the national commitment to reconciliation is well on its way. Religious leaders from different religious groups should sit together and discuss ways and methods to improve inter-communal harmony. As part of the ethno-religious reconciliation process, the Sri Lankan government must also reform the existing legal structure so as to instill more discipline among the religious groups and movements and their activities. Since Sri Lanka is a small country with very few ethnic divisions, it would not be hard to strengthen ethnic reconciliation and build social harmony if all actors in the post-war reconciliation process are united and committed to the process.

Acknowledgments: This study is self-funded by the authors. We thank the reviewers for their valuable comments and suggestions which were highly supported and motivated us to further improve the paper.

Author Contributions: All authors have equally contributed in the development and completion of this study and this paper.

Conflicts of Interest: The authors declare no conflict of interest. 


\section{Abbreviations}

The following abbreviations are used in this paper:

$\begin{array}{ll}\text { ACJU } & \text { All Ceylon Jamiatul Ulama } \\ \text { BBS } & \text { Bodu Bala Sena } \\ \text { HAC } & \text { Halal Accreditation Council } \\ \text { JHU } & \text { Jathika Hela Urumaya } \\ \text { LTTE } & \text { Liberation Tigers of Tamil Ealam } \\ \text { PTA } & \text { Prevention of Terrorism Act } \\ \text { SJB } & \text { Sinhala Jathika Balamuluwa } \\ \text { SLMC } & \text { Sri Lanka Muslim Congress } \\ \text { UNF } & \text { United National Front }\end{array}$

\section{References}

1. Siriwardena, Rapti. War, Migration and Modernity: The Micro-Politics of the Hijab in Northeastern Sri Lanka. Bonn: Department of Political and Cultural Change, University of Bonn, 2014.

2. Department of Census and Statistics. Census of Population and Housing-2012 (New)_Final Report. Colombo: Department of Census and Statistics, 2014, Available online: http://www.statistics.gov.lk/PopHouSat/ CPH2012Visualization/htdocs/index.php?usecase=indicator\&action=Map\&indId=10 (accessed on 24 October 2015).

3. Ameer, Ali. Plural Identities and Political Choices of the Muslim Community. Colombo: Marga Institute, 2001.

4. Ameer, Ali. "The Muslims of Sri Lanka: An ethnic minority trapped in a political quagmire." Inter-Asian Cultural Studies 5 (2004): 372-83.

5. McGilvray, Dennis B. “Arabs, Moors and Muslims: Sri Lankan Muslim ethnicity in regional perspective." Contributions to Indian Sociology 32 (1998): 433-83. [CrossRef]

6. Ismail, Jezima. "A tribute to the cordial relations between Muslims and Sinhalese in the past." Colombo Telegraph, 23 February 2013. Available online: https://www.colombotelegraph.com/index.php/a-tribute-tothe-cordial-relations-between-muslims-and-sinhalese-in-the-past/ (accessed on 20 March 2016).

7. Yusoff, Mohammad Agus, Nordin Hussin, and Athambawa Sarjoon. "Positioning Muslims in ethnic relations, ethnic conflict and peace process in Sri Lanka." Asian Social Science 10 (2014): 199-211. [CrossRef]

8. Razick, Ahamed Sarjoon, Ahmad Sunawari Long, and Kamarudin Salleh. "Historical relationship between the Buddhists and Muslims in Sri Lanka." Mediterranean Journal of Social Sciences 6 (2015): 278-84. [CrossRef]

9. Ameen, Mohamed Ibrahim Mohamed. Ilankai Muslimkalin Waralarum Kalasaramum 1870-1915 (The History and Culture of the Muslims of Sri Lanka). Hemmathagama: Al-Hasanath Publication, 2000.

10. Naleemi, Raifai. "Accusations, Sinhala Kings, history and the Muslims in Sri Lanka." Colombo Telegraph, 8 April 2013. Available online: https://www.colombotelegraph.com/index.php/accusations-sinhala-kingshistory-and-the-muslims-in-sri-lanka/ (accessed on 30 May 2016).

11. Dewaraja, Lorna Srimathie. The Muslims of Sri Lanka, 1000 Years of Ethnic Harmony 900-1915 AD. Colombo: Lanka Islamic Foundation, 1994.

12. Jones, Robin Noel Badone. "Sinhala Buddhist nationalism and Islamophobia in contemporary Sri Lanka." Bachelor's Thesis, Bates Collage, Lewiston, ME, USA, 30 March 2015.

13. Kumari, Jayawardena. Ethnic and Class Conflict in Sri Lanka. Madras: Kumaran Publishers, 1985.

14. Aliff, Seeni Mohamed. "Post-war conflict in Sri Lanka: Violence against Sri Lankan Muslims and Buddhist hegemony." International Letters of Social and Humanistic Sciences 59 (2015): 109-25. [CrossRef]

15. Getaberiya, Rushdy Nizar. "Post-war and the contemporary cold war against the minority in Sri Lanka." Colombo Telegraph, 10 June 2013. Available online: https:/ / www.colombotelegraph.com/index.php/postwar-and-the-contemporary-cold-war-against-the-minority-in-sri-lanka/ (accessed on 20 January 2016).

16. Center for Policy Alternatives. Attacks on Places of Religious Worship in Post-War Sri Lanka. Colombo: Center for Policy Alternatives, 2013.

17. BBC News. "Sri Lankan Muslims Strike over Dambulla Mosque." 26 April 2012. Available online: http:/ / www.bbc.com/news/world-asia-17852900 (accessed on 28 May 2016).

18. Wickramasinghe, Nira. Sri Lanka in the Modern Age: A History. New York: Oxford University Press, 2014. 
19. Secretariat for Muslims. Anti-Muslims Sentiment in Sri Lanka: Incidents against Muslims-May to August 2015. Colombo: Secretariat for Muslims, 2015, Available online: http://sfmsl.org/wp-content/uploads/2015/11/ Anti-Muslim-Sentiment-in-Sri-Lanka_May-August_2015.pdf (accessed on 10 February 2016).

20. Hussain, Izeth. "Sri Lanka Muslims at the cross road-animal sacrifice and other issues." Colombo Telegraph, 10 October 2014. Available online: https:/ /www.colombotelegraph.com/index.php/sri-lankan-muslims-atthe-cross-roads-animal-sacrifice-and-other-issues/ (accessed on 13 January 2016).

21. Haniffa, Farzana. "Fecund mullas and goni billas: The gendered nature of anti-Muslim rhetoric in post war Sri Lanka." The South Asianist 4 (2015): 1-24.

22. Ranabahu, Kosala. "No coercion, no logo, assures new halal body." The Sunday Times, 12 January 2014. Available online: http://www.sundaytimes.lk/140112/news/no-coercion-no-logo-assures-new-halalbody-79665.html (accessed on 29 May 2016).

23. Fraser, Kym. "Slaughter of Animals: Why 'Halal' Meat is 'Harm'." The Sunday Times, 5 May 2013. Available online: http:/ / www.sundaytimes.lk/130505/sunday-times-2/slaughter-of-animals-why-halal-meat-isharam-43092.html (accessed on 12 January 2016).

24. Senarathne, L. B. "Kandy MC Bans Animal Slaughter within Municipal Limits." Available online: http: / / www.infolanka.com/news/IL/dm788.htm (accessed on 30 May 2016).

25. Tissainayagam, J. S. "Sri Lanka in anti-Muslim waves after Buddhist monk's suicide." Lanka on Globe, 28 May 2013. Available online: https://lankaonglobe.wordpress.com/2013/05/28/sri-lanka-in-antimuslim-wave-after-buddhist-monks-suicide/ (accessed on 30 May 2016).

26. Wimalaweera, Nirushi. "Import beef from abroad-President." Daily News, 19 January 2016. Available online: http:/ /www.dailynews.lk/?q=2016/01/19/local/import-beef-abroad-president (accessed on 30 May 2016).

27. Nathaniel, Camelia. "Undressing the Hijab harassment." The Sunday Leader, 16 March 2014. Available online: http://www.thesundayleader.lk/2014/03/16/undressing-the-hijab-harassment/ (accessed on 29 May 2016).

28. Siriwardena, Rapti. War, Migration and Politics of Hijab in North-Eastern Sri Lankan. Bonn: Center for Development Research (ZEF), University of Bonn, 2014.

29. Ayesha, Zuhaira. Dynamics of Sinhala-Buddhist Nationalism in Post-War Sri Lanka. Colombo: Center for Policy Alternatives, 2016.

30. BBC News. "The hardline Buddhists targeting Sri Lanka's Muslims." 25 March 2013. Available online: http:/ /www.bbc.com/news/world-asia-21840600 (accessed on 13 April 2016).

31. Colombo Telegraph. "Unedited full video: BBS Gnanasara's pre-riots speech." 19 June 2014. Available online: https:/ / www.colombotelegraph.com/index.php/unedited-full-video-bbs-gnanasaras-pre-riotsspeech/ (accessed on 20 April 2016).

32. Gunatilleke, Gehan. "Hate speech in Sri Lanka: How a new ban could perpetuate impunity." Oxford Human Rights Hub, 11 January 2016. Available online: http:/ / ohrh.law.ox.ac.uk/hate-speech-in-sri-lanka-how-anew-ban-could-perpetuate-impunity/ (accessed on 25 April 2016).

33. Colombo Telegraph. “'Sinha Le' hate speech must be dealt with new law: NPC.” 16 January 2016. Available online: https:/ / www.colombotelegraph.com/index.php/sinha-le-hate-campaign-must-be-dealt-with-bynew-law-npc/ (accessed on 20 April 2016).

34. Department of Census and Statistics. Census of Population and Housing. Colombo: Department of Census and Statistics, 1981.

35. Jayawardena, Kumari. "Economic and political factors in the 1915 riots." The Journal of Asian Studies 29 (1970): 223-33. [CrossRef]

36. Stewart, James John. "Muslim Buddhist conflict in contemporary Sri Lanka." South Asian Research 34 (2014): 241-60. [CrossRef]

37. Yusoff, Mohammad Agus, Nordin Hussin, and Athambawa Sarjoon. "Muslim demand for territorial autonomy in the eastern Sri Lanka: An analysis of its origin, development and the present stance." Asian Social Science 10 (2014): 76-88. [CrossRef]

38. McGilvray, Dennis B., and Mirak Raheem. Muslim Perspectives on the Sri Lankan Conflict. Washington: East-West Center, 2007.

39. Jeyaraj, David Buell Sabapathy. "Oluvil declaration proclaims advent of Muslim thesam (nation)." The Sunday Leader, 2 September 2003, p. 14.

40. Issadeen, Segu, and Mohamed Hasan. Muslim Autonomy. Colombo: Muslim Nationalists Movement, 2006. 
41. Venugopal, Rajesh. "Sectarian socialism: The politics of Sri Lanka's Janatha Vimukthi Peramuna (JVP)." Modern Asian Studies 44 (2010): 567-602. [CrossRef]

42. DeVotta, Neil. "Engaging Sinhalese Buddhist majoritarianism and countering religious animus in Sri Lanka: Recommendations for the incoming U.S. administration." The Review of Faith \& International Affairs 14 (2016): 76-85. [CrossRef]

43. Berkley Center for Religion, Peace and World Affairs (BCRPWA). Sri Lanka: Civil War along Ethnoreligious Lines. Washington: BCRPWA, 2013.

44. Gravers, Mikael. "Anti-Muslim Buddhist nationalism in Burma and Sri Lanka: Religious violence and globalized imaginaries of endangered identities." Contemporary Buddhist: An Interdisciplinary Journal 16 (2015): 1-27. [CrossRef]

45. International Crisis Group (ICG). Sri Lanka's North: The Denial of Minority Rights. Brussels: ICG, 2012.

46. Hensman, Rohini. "Post-war Sri Lanka: Exploring the path not taken." Dialectical Anthropology 39 (2015): 273-93. [CrossRef]

47. Isaacs, Matthew. "Why are Buddhist monks promoting violence in Sri Lanka?" Political Violence at a Glance, 1 July 2014. Available online: https:/ / politicalviolenceataglance.org/2014/07/01/why-are-buddhist-monkspromoting-violence-in-sri-lanka/ (accessed on 21 April 2016).

48. Green, Penny. "Islamophobia: Burma's racist frontline." Race and Class 55 (2013): 93-98. [CrossRef]

49. International Crisis Group (ICG). The Dark Side of Transition: Violence against Muslims in Myanmar. Brussels: ICG, 2013.

50. Jayatilleka, Dayan. "Anti-Muslim Extremism and Dilemmas of Diversity in Sri Lanka." Colombo Telegraph, 13 February 2013. Available online: https://www.colombotelegraph.com/index.php/anti-muslimextremism-and-dilemmas-of-diversity-in-sri-lanka/ (accessed on 30 March 2016).

51. Kumar, Krishna. Promoting Social Reconciliation in Post-Conflict Societies: Selected Lessons from USAID's Experience. Washington: Center for Development Information and Evaluation, 1999.

52. Akashi, Yasushi. "Greetings and observation of the Balkans in the global context." In Inter-Ethnic Reconciliation, Religious Tolerance and Human Security in the Balkans: Proceeding of the Second ECPD International Conference. Edited by Takehiro Togo, Jeffrey Levett and Negoslav P. Ostojić. Beograd: European Center for Peace and Development (ECPD) of the United Nations University for Peace, 2006, pp. 3-6.

(C) 2016 by the authors; licensee MDPI, Basel, Switzerland. This article is an open access article distributed under the terms and conditions of the Creative Commons Attribution (CC-BY) license (http://creativecommons.org/licenses/by/4.0/). 